\title{
Research Paper: Assessing the Relationship between the Performance of Rural Municipalities and the Realization of Good CrossMark Rural Governance (Case Study of the Central Part of Zanjan City)
}

\author{
Esmael Nasiri HandehKhaleh $^{1^{*}}$, Shahram Amin Entekhabi ${ }^{2}$, Seyedeh Yasaman Mohagheghpour ${ }^{3}$
}

1. Department of Geography and Urban Planning, Faculty of Social Sciences, Payame Noor University, Tehran, Iran

2. Department of Geography and Rural Planning, Faculty of Social Sciences, Payame Noor University, Tehran, Iran.

3. Department of Urban Planning, Faculty of Art and Architecture, University of Science and Research, Tehran, Iran.

\begin{tabular}{|l|l|}
$\begin{array}{c}\text { Use yourdevice to scan } \\
\text { and reat the article online }\end{array}$ & $\begin{array}{l}\text { Citation: Nasiri HandehKhaleh, E., Amin Entekhabi, Sh. \& Mohagheghpour, S. Y. (2020). Assessing the Relationship be- } \\
\text { tween the Performance of Rural Municipalities and the Realization of Good Rural Governance (Case Study of the Central Part } \\
\text { of Zanjan City). Journal of Sustainable Rural Development, 4(2), 215-228. https://doi.org/10.32598/JSRD.4.2.9 }\end{array}$ \\
dol: $:$ https://doi.org/10.32598/JSRD.4.2.9
\end{tabular}

\section{Article info:}

Received: 14 Sep. 2019

Accepted: 15 Jan. 2020

Keywords:

Rural Municipalities, Rural Governance, Good Governance, Zanjan Province

\begin{abstract}
A B STRACT
Purpose: Rural Government is considered as a way to extend democracy, empower villagers to choose their way of life and organize their living space, increase prosperity, create opportunities, and promote teamwork, and it can be concluded that in new rural government theories, rural municipalities are the new paradigm and one of the main pillars of rural management and development. By the end of September 2009, there were 898 villages with more than 20 households and 194 authorized rural municipalities in Zanjan province, Iran and the number of rural municipalities compared to villages with more than twenty households was about $\% 21.6$. This study aims to investigate the performance of rural municipalities in the rural government of Zanjan province.
\end{abstract}

Methods: Our research method is of documentary-field type and the study population consists of 194 rural municipalities from which 114 were selected as the sample using stratified sampling with proper allocation. SPSS was used to analyze the data. For stepwise regression, the variables were entered into the equation as factors affecting the performance of rural municipality in rural government by which $89 \%$ of Zanjan rural municipality performance variance was clarified.

Results: The results show that the performance of rural municipalities in the selected area can play a critical role in villagers' participation in rural management and development. The more participation, the better the performance of rural municipalities will be.

Conclusion: Based on the results, the variables with a significant effect on rural government are the cooperation of rural council, villagers' participation, rural equipment and facilities, and rural municipality consultation with local leaders and council members.

* Corresponding Author:

Esmael Nasiri HandehKhaleh, PhD

Address: Department of Geography and Urban Planning, Faculty of Social Sciences, Payame Noor University, Tehran, Iran.

Tel: +98 (912) 2389852

E-mail: esmael.nasiri@yahoo.com 


\section{Introduction}

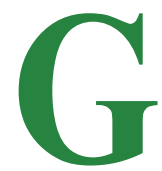

overnance is a process. This process involves an interconnected system that encompasses both government and society. In fact, the interaction between the people and the government is developed through the mobilization of communities to participate in social and economic activities (Parhizkar \& Kazemiyan, 2005). The main objective of a good government is to encourage productive interactions between communities (Barakpour, 2010).

The role of the state in the political-economic transformation of the governance of rural regions towards a 'new rural paradigm' is changing from a provider of services and driver of industrialisation to an enabler and moderator of participatory development (Müller et al., 2020).

Main objectives of governance are social reconstruction in order to further strengthen and moderate institutions, organizations and local communities, poverty alleviation and reduction of social, ethic and cultural integration in rural areas, oneness and collaboration based on trust among actors in the private and public sectors, active and effective participation of villagers and social communities based on justice and consensus, effectiveness and efficiency in sustainable rural development and services with optimal use of rural resources, facilitation, empowering villagers instead of controlling rural affairs, developmentalism based on anthropocentrism and social, economic and environmental sustainability (Parhizkar \& Kazemian, 2005).

Good rural governance is a prerequisite for sustainable rural development. By establishing good rural governance in the rural environment, decentralization, rural resource management, and public participation, the partnership between the government and civil society and the private sector can be institutionalized in the rural community (Pazoki et al., 2020).

Stern describes the criteria of good government as follows: accountability, transparency, and institutional structures (Scott, 2001).

Governance is not a novel concept. It is referred to as accountability in policy-making and execution. In the simplest words, governance is a decision-making process by which the decisions are executed. Governance is used in different integrated, international, national, and local contexts (Akbari, 2003). In this paper, the role of rural municipalities as an instrument for rural gover- nance policies is investigated. The rural governance approach toward management can be considered the peak of rural management science because the approach widens the villagers' field of action and increases their power to act (Nemati \& Badri, 2007). The effectiveness of rural management and the role it plays in accelerating the rural governance process is one of the main factors influencing rural development. A study of the rural management paradigm over the past decades shows that the bottomup planning approach has been replaced by the top-down planning approach to institutionalize public participation (Zabetian, 2010). After the Iranian Revolution, modern rural management has been in line with the development programs, and in recent years, it experienced new rural management in the form of sustainable development and a people-oriented approach. Following the changes in rural affairs laws to achieve bottom-up development, rural councils and consequently rural municipalities were established (Imani Jajermi, 2010).

Obviously, part of the efficiency of rural management, especially rural municipalities, depends on how policies are adopted (Hamidian et al., 2007).

A rural municipality is a non-governmental organization established to manage rural affairs. Upon the establishment of rural municipalities (2003), all villages with more than 20 households could get authorization from the provincial government to establish their rural municipality, provided that the villagers paid the self-help cost (Akbari, 2003).

A rural municipality, as a local organization, communicates with the central government through its official representatives in the region, i.e. provincial government and governorate, and with people through the rural council (Nemati, 2007).

If the rural government is to be considered as a way to extend democracy, empower villagers to choose their way of life and organize their living space, increase prosperity, create opportunities, and promote teamwork, it can be concluded that in new rural government theories, rural municipalities are the new paradigm and one of the main pillars of rural management and development.

Zanjan province is one of the finest examples of executing this management approach. Considering the 5-year experience of this new managment organization in villages, we investigated the effect of rural municipalities on the rural governance system. 
The aim of present research is to study the ability of villagers to organize rural affairs, better participation of villagers in executive affairs, creating a social foundation in villages, and reducing government involvement in rural affairs.

In addition, the question we are trying to address is: do rural municipalities pave the way for the governance of the communities? To answer the question, the following assumptions are made:

\section{Hypothesis 1}

$\mathrm{H} 1$ : It seems that the rural governance system is a function of the performance of rural municipalities.

\section{Hypothesis 2}

$\mathrm{H} 2$ : The performance of rural municipalities in villages of Zanjan have a positive effect on the rural governance system in terms of villagers' participation in rural management, developing rural technology, providing public services in rural areas, strengthening rural infrastructures, creating a socio-cultural foundation in villages and reducing government involvement in rural affairs.

\section{Literature Review}

Rural management as the smallest social administrative unit has been discussed since the advent of the Persian Constitutional Revolution. In the first legislation ratified by the National Consultative Assembly, village management was entrusted to the alderman who was a villager and chosen by the owner. For about a hundred years, this approach was the main way of rural management until the Iranian land reform era, during which the government took control of the rural affairs, owners were deprived of their power and rural governance experienced fundamental changes (Taleb, 2010). The rural management system in Iran underwent complex social structure changes over the years. Modern rural management is based on the capacity of local communities, the emergence of creativity, collectivism and participation, and analysis of socioeconomic issues in villages. As a new approach to rural management, rural municipalities pave the way for villagers to govern themselves (Mahdavi \& Najafi, 2005).

Therefore, diversifying the rural economy by relying on management in developing countries has improved non-agricultural job opportunities in rural areas and also has an important impact on the well-being of rural households. It also reduces the risks of agricultural prod- ucts and offers more options, and ultimately distributes the output of the social system more equitably among its vital components (Demurger, Martin, Weiyong, 2010). This leads to economic changes and sustainable rural development. It is obvious that the social unit of the village in terms of the existence of social and economic relations is definitely in need of a management organization. Since achieving sustainable development is one of the main goals of macro-policies in the country, the concept of sustainable development has been developed in response to increasing awareness of the existence of several important links between human and economic development processes, global environmental problems and localization, population growth and poverty, and political change (Manal, Bachir \& Nadim, 2008).

Rural management is an organizational process by with institutes and organizations are formed to lead rural society and manage the environment (Rezvani, 2004). Conceptually, a rural municipality is a social organization that is consciously coordinated, has relatively specified boundaries and aims for a goal or set of goals. A rural municipality is a local organization taken into consideration as a result of changes in management methods. Local organizations are based on the principle of "the rule of people over people" and participation is the basic principle of these organizations (Rezvani, 2004). A rural municipality, as a local organization, communicates with the central government through its official representatives in the region, i.e. provincial government and governorate and with people through the rural council. Administrative and financial independence is one of the key features of local organizations (Alavi Tabar, 2000). According to the statutes of rural municipalities, 47 duties are identified for the rural municipality administrator. Some executive tasks with all the required financial resources are assigned to the rural municipality administrator, based on his abilities (Ghorbani, 2004).

Some experts believe that, technically, the existence of rural municipalities as local organizations requires three main characteristics:

\section{1) Organization}

2) Governmental characteristics

3) Financial and administrative independence (Moghimi, 2003).

Rural management is one of the most important pillars for achieving sustainable development. In fact, rural management is the science of integrating and regulating 
various natural, human and economic factors in the rural community and the process of organizing and directing the rural community and the environment through the formation of organizations and institutions. In the new development approach, local identity is the infrastructure of local governance and local governance is a key tool for sustainable rural development. Accordingly, the approach of management based on local community seems to be a good approach because it emphasizes the local community empowerment and their direct and active role in the development process in collaboration with the public sector and non-governmental organizations. The good rural governance approach is one of the newest and most popular approaches to sustainable rural development management that has been discussed so far. Good rural governance is a precondition for sustainable rural development, because decentralization, rural resource management, public participation, partnerships between government and civil society and the private sector are considered key tools to respond to social, economic and environmental needs and all these require the establishment of a good rural governance approach (Pazoki et al., 2020).

Nowadays, the recommendation to implement good governance is increasingly appearing in studies on local development. The idea of good governance presupposes the use of various forms and tools of civic participation and a diversity of participants in the process of co-management. Citizens' control (through transparency and accountability), openness, participation, efficiency and effectiveness in the exercise of power are the key principles of the "governance" approach in public sector management (Guzal-Dec, 2020).

In recent years, rural governance has been the main focus of development researchers and policymakers. Every country has its own reasons to put rural governance under consideration including increased pressure on local governments due to multiple tasks that need to be handled without the necessary support, reduction of central government resources and aid payments, the necessity to improve local government efficiency, territory challenges, and complexity of the inter-institutional relations.

Governance refers to the decision-making process and the framework of relationships between different actors in the process including governmental and non-governmental organizations, public voluntary associations, etc.

The concept of governance in studies and activities for rural areas emphasizes features and principles such as establishing links between different actors of development, rural policy integration, cooperation between areas of management, paying more attention to sustainable rural participation, mapping out participatory goals and perspectives, attention to local and competitive advantages, capacity building and improving the capabilities of local authorities, etc. (Barakpour, 2010). To be more specific, a comprehensive system of rural governance in which public participation is a fundamental principle will not be accomplished without the validation of local leaders, believing in their actual and potential abilities and establishing public organizations (Mahdavi \& Najafi, 2005). Rural governance approach is very important and includes populism, participation and endogenous development (Zankin, 2010).

Rural management in the form of rural municipality is a platform for rural development which has cultural coordinates in terms of content and appearance and indicates organic transformation, due to the fact that it is a human achievement. The goal of development is to create a prosperous life defined by culture. The development of rural areas is important, especially in developing countries where people are more deprived. In today's world, villagers have an unfavorable situation in terms of living standards and welfare (Riahi \& Nouri, 2014).

Renovation in the field of rural development includes several theories with different tendencies. One of the major theories is the governance and participation of villagers in rural management. Based on this theory, if the economic and social change plans are not based on the perception of villagers, they will fail (Bahrainian, 2008). Some experts believe that fulfillment of local and rural management in the form of the rural municipality which is referred to as governance depends on the formation of a set of official relationships and structures such as rule of law, codified clear legal frameworks, defined and specified power limits of political regimes, determined levels of decentralization and provided conditions for participation in decision-making on rural policies and development.

Cryan believes that governance is progress that requires fundamental changes in social structures, national institutes and people's perception, acceleration of economic growth, decreasing inequalities and poverty alleviation. A theoretical literature review of governance shows that although the concept has gained more attention in the last few years, it is deeply rooted in history. The nature of governance in the interaction between the actors and effective forces of a rural community on a local, regional and national scale, and the need for convergence and 
alignment in a framework based on local democracy and spatial justice are the most important arguments to justify the need for establishing a rural governance model in rural areas (Darban Astane, 295:1389).

Rural governance is when people reach a level of individual development that enables them to choose based on their demands. Rural governance is a term to describe the facilitation of rural participation in achieving rural development goals (Farokhi, 2005).

There are 8 main features to rural governance: consensus, equality and inclusiveness, effectiveness, accountability, rule of law, transparency, participation and responsibility (Akbari, 2006).

The concept of governance in the simplest definition is the decision-making process and the process by which decisions are made.

Governance is used in a variety of contexts, such as unified, international, national, and local governance. In this study, the performance of municipalities as the most important management institution within the villages on the rural governance system is evaluated.

In the following the previous researches on this topic are mentioned:

Norouzi et al. (2017) in a study conducted with the aim of evaluating the performance of rural municipalities based on good governance indicators in the central part of Isfahan city concluded that there is a significant difference between rural municipalities in the study area based on the studied indicators and the performance of all villages in the mentioned indicators is weaker than desirable (Norouzi, Mahdavi \& Badrizadeh, 2017).

Heidari Sareban et al. (2017) also evaluated the effects of governance on the development of rural tourism in the city of Nir and concluded that improving governance indicators leads to the development of rural areas in all dimensions, especially rural economy and tourism (Heydari Sarban, Arshadi, Saeb, 2017).

Najarzadeh et al. (2017) also studied the effect of social capital on good governance and sustainability of rural communities in Godin district of Kangavar city and concluded that the indirect effects of social capital have a significant relationship with socio-economic sustainability. Cultural capital also moderates the relationship between good rural governance and socio-cultural sustainability (Najarzadeh, Torabi \& Malekan, 2017).
Hesam et al. (2014) in a study conducted to measure satisfaction with the performance of rural municipalities with a good rural governance approach in Gonbad city, found that satisfaction with the performance of rural municipalities in this rural area is at a good level (Hesam, Rezvani \& Ashour, 2014).

Beer (2014) in a study aimed at examining the importance of leadership and local governance in rural communities, found that there is a strong relationship between leadership and local governance in rural communities and they serve the government through existing spaces and on a spatial scale (Beer, 2014).

Elmenofi et al. (2014) in a study on the role of local governments in rural development in Egypt also found that many rural local organizations in the study area lack coordination in funding and community participation, which is considered a major challenge in rural development (Elmenofi, Bilali \& Berjan, 2014).

Ajza Shokouhi and Eastgoldi (2013) in a study entitled "Analysis of the Underlying Factors of Good Governance", concluded that the variable of social trust has the highest relationship with the quality of good governance (Ajza Shokouhi \& Eastgoldi, 2013).

Riahi and Karimi Nasab (2013) in their article entitled "Evaluation of Rural Municipalities Performance in the Spatial-Physical Development of Rural Settlements (Case study: Kurdish District of Jahrom City)" stated that from the perspective of villagers, significant changes in villages are observed in the indicators of quality of construction and stabilization and documentation of properties in the village, and in the field of administrative-disciplinary indicators and educational services, few changes are observed. From the point of view of households living in the village, in the study of rural performance, improvement and rehabilitation of housing and the quality of public services in the village have been considered positive and the location of services and facilities has been considered negative (Riahi \& Karimi Nasab, 2013).

Farahani and Rostamkhani (2013) in their article entitled "Study and Evaluation of the Role of Rural Development on the Quality of Life in the Villages of Karsaf Rural District of Khodabandeh City", state that to compare the quality of life in the sample villages, 8 indicators including educational, environmental, social, and economic indicators, health and safety support networks, residential environment, infrastructure and leisure were examined and evaluated. Based on the results, out of 8 
indicators, in 7 indicators there was a significant difference between villages with rural municipalities and villages without rural municipalities and only in the field of leisure, no significant difference was observed (Farahani and Rostamkhani, 2013).

Wenchang (2008) in a study entitled "Rural Management, The Way Out for Tibetan Rural Areas", concludes that rural management finds its place in rural areas when combined with rural culture, rural resources, rural ecology, rural production, reducing rural poverty and improving rural life in functional interaction (Wenchang, 2008).

Nemati's research illustrated that rural municipality success is closely related to villagers' participation. Participation in rural municipality activities is highly dependent on the social and cultural conditions of the village (Nemati, 2007).

Choubchian et al. (2007) by evaluating the factors influencing the performance of rural municipalities in Guilan, showed that a good level of participation leads to a better performance by the rural municipalities (Choubchian et al., 2007).

Morita and Zaelke (2007) in a study conducted to investigate the role of law in good governance and sustainable development concluded that good governance has a fundamental and important role in natural resource management, economics and sustainable development (Morita and Zaelke, 2007).

Rezvani's research shows that rural municipality is the perfect example of local organization management in which the mainstay is participation (Rezvani, 2004).

Madani's research about the performance of rural municipalities in Mazandaran indicates more participation of villagers in rural development (Madani, 2003).
Welch (2002) in a study on the legitimacy of rural local government in the South Island of New Zealand and Victoria, Australia, argued that good rural governance requires a fair and equitable legal framework to be implemented impartially (Welch, 2002).

Alipour investigated the effect of rural council and municipality on villagers' participation in Semnan province (Alipour, 2001).

Noroozifar's research shows that although local organizations (e.g. rural municipality) are different from government and private organizations, they are public organizations established in a specific region of a country according to public laws to provide people of that region with necessary services (Norouzifar, 2001).

Goodwin (1998) in a study on the governance of rural areas and attention to rural development based on participation, considers rural governance as a tool of power and the subject of social production (Goodwin, 1998).

\section{Methodology}

\section{Case Study of the research}

The study area is the villages of the central part of Zanjan city. Zanjan city is located in Zanjan province in the northwest of Iran. This province shares borders with the provinces of East and West Azerbaijan, Ardabil, Guilan, Qazvin, Kurdistan and Hamedan. Zanjan city has three parts, namely, the central part, Zanjanrood and Qare Pashtloo. According to the results of the 2016 census, the central part of Zanjan city has a rural population of 51154 (14676 households) and six villages. This rural population lives in 114 permanently inhabited villages. Table 1 shows the demographic characteristics of the city and Figure 1 shows the study area.

Table 1. The study questions in the questionnaire

\begin{tabular}{ccccc}
\hline District & Rural District & No. of Villages & Household & population \\
\hline \multirow{4}{*}{ Central } & Bonab & 32 & 4299 & 14146 \\
& Buqda Kandi & 14 & 2227 & 7133 \\
& Taham & 9 & 811 & 2578 \\
& Zanjanrud-e Bala & 26 & 2951 & 13572 \\
& Mojezat & 24 & 3119 & 10195 \\
Total & Qoltuq & 9 & 1269 & 3530 \\
\hline
\end{tabular}

Source: Statistical Centre of Iran 
$M a p$ of $v i l$ l a ges i n Z a njan County

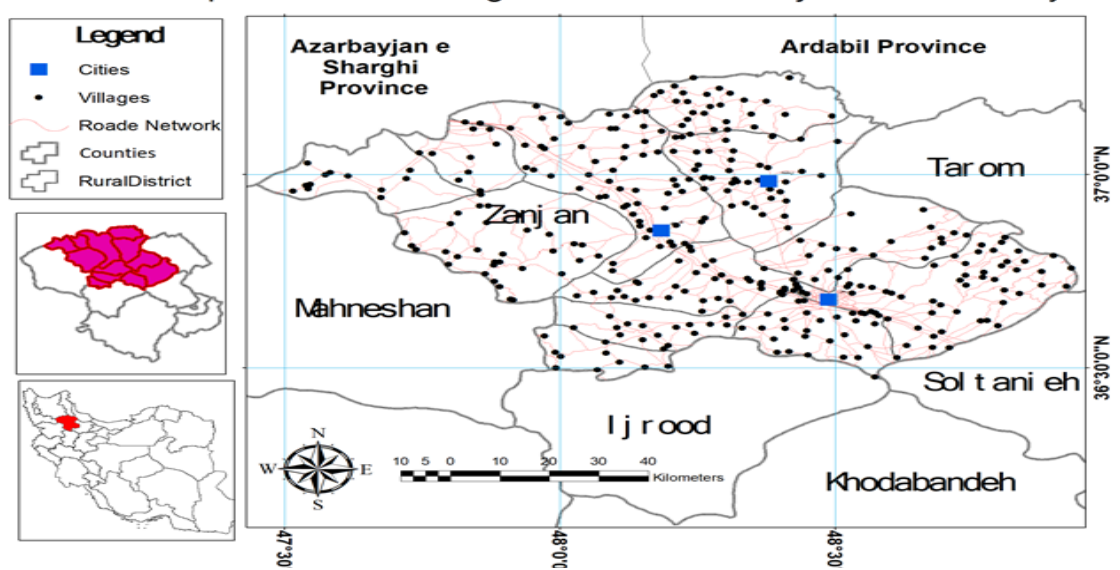

Figure 1. Location map of the study area

\section{Methodology:}

The research method is library and field research and a questionnaire was used to collect data. The study population consists of rural municipalities and heads of households in central Zanjan province. SPSS software was used to analyze the data. The sample size was calculated using the Cochran equation.

The questionnaire consists of two parts: general and specific questions. Specific questions have been designed on the dimensions of rural performance indicators and their impact on good rural governance. The validity of the questionnaire was reviewed based on the opinion of experts and Cronbach's alpha method was used to determine the reliability of the questionnaire and Cronbach's alpha coefficient was obtained 0.862 .

In order to select the criteria of good rural governance, related sources and documents were examined and also by referring to the main indicators of good governance provided by the United Nations Development Programe, the research criteria were extracted.

The criteria for the performance of rural municipalities in terms of achieving good rural governance:

- Developing rural technology

- Villagers' access to financial resources

- Creating job opportunities

- Motivating villagers

- Creating a socio-cultural foundation in villages
- Reducing government involvement in rural affairs

\section{Good Rural Governance Criteria:}

- Participation

- Responsiveness

- Responsibility

- Equity

- Transparency

According to research criteria and indicators and based on research literature, the conceptual framework of the research is as follows.

\section{Findings}

The effect of the performance of rural municipality on the level of empathy, participation and localism in rural management:

The results of the questionnaires show that $79 \%$ of the total villages surveyed stated that with the creation of rural municipalities, the participation of villagers has increased. In the above field, the following results were obtained:

Islamic councils of 85 villages out of the total number of villages surveyed thought that their village would be the best place to live by creating rural municipality.

The results showed that localism in rural management is highly common among the rural council members in 
a way that $84 \%$ of council members believed that their village is almost the perfect place to live.

The effect of the rural municipalities on technology in rural areas:

This issue was investigated using the following question in the questionnaire: Does the establishment of the rural municipality provide any platform for innovation in rural services? The council members of 40 villages stated that they had used novel devices and methods for production in recent years. These innovations mostly influenced by the rural municipality include a wide range of agricultural, industrial, or even service applications.
As can be seen in Table 2, more than $57 \%$ of respondents evaluated the effect of the rural municipality on rural access to financial resources higher than average.

The effect of the rural municipalities on access to financial resources:

The regression coefficient and $\mathrm{F}$ test indicate the significant effect of rural access to financial resources on the empowerment of villagers.

The regression coefficient and $\mathrm{F}$ test indicate the significant effect of the rural municipalities on the empowerment of villagers.

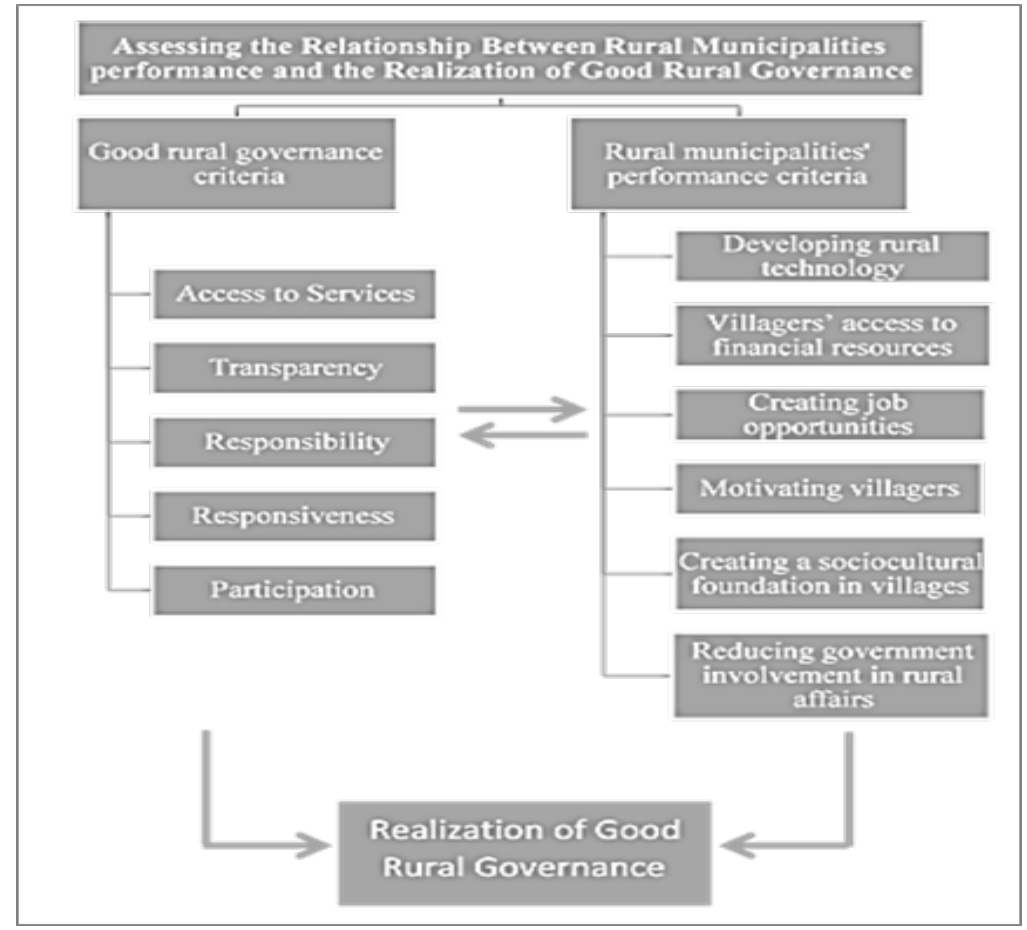

Figure 2. Conceptual framework of the research

Table 2. The effect of rural performance on access to financial resources

\begin{tabular}{cccccc}
\hline $\begin{array}{c}\text { Ability } \\
\text { Income }\end{array}$ & Low & Medium & High & Very high & Total \\
\hline down & 5 & 22 & 35 & 22 & 100 \\
\hline medium & 1 & 14 & 28 & 48 & 100 \\
\hline Top & 0 & 30 & 11 & 49 & 100 \\
\hline Total & 5.1 & 20 & 30 & 33 & 100 \\
\hline
\end{tabular}

sig: $0.000 \quad$ F: $29.3 \quad$ R: 0.207


Regression analysis results illustrated that the effect of the rural municipality on access-to-financial-resources variables including the elimination of discrimination in the labor market, property rights, increasing the level of participation, cooperation with rural council and motivating the villagers is directly related to independent research variables.

$74 p$ is equal to $0.292,72 p$ is equal to $0.933,75 p$ is equal to $0.126,76 \mathrm{p}$ is equal to $0.04,73 \mathrm{p}$ is equal to 0.210 , and $71 \mathrm{p}$ is equal to 0.095 . These figures show the direct effect of independent research variables on the dependent variable.

The effect of the rural municipalities on social and cultural issues:
The results showed that rural municipalities were most effective in promoting the teamwork spirit among villagers so that $89.8 \%$ of respondents believed it.

Tables 4 and 5 indicate that rural municipalities were most effective in reducing government involvement in rural affairs with an average of $5.2 \%$. Promoting the teamwork spirit among villagers, strengthening life management skills, increasing villagers' awareness of their potential abilities for problem-solving, providing the proper conditions to create job opportunities in rural areas and creating a socio-cultural foundation in rural areas are among other achievements of rural municipalities regarding social and cultural issues. The results of average ranks and standard derivation prove the same.

Table 3. Results of regression analysis of the effect of rural performance

\begin{tabular}{ccccc}
\hline \multicolumn{1}{c}{ variable } & & Correlation & Correlation & Indirect effect \\
\hline $\begin{array}{c}\text { Access to financial resources } \\
\text { Elimination of discrimination from the labor market in } \\
\text { rural areas }\end{array}$ & P71-r 71 & 0.22 & 0.088 & 0.117 \\
$\begin{array}{c}\text { Having the right to legal ownership in the villages } \\
\text { Increasing the level of participation }\end{array}$ & P73-r73 & 0.204 & 0.087 & 0.114 \\
\hline Cooperation in the Islamic Council & P74- r74 & 0.327 & 0.22 & 0.212 \\
\hline Motivating the villagers & P75-r75 & 0.271 & 0.21 & 0.118 \\
\hline Source: Research findings & P76-r76 & 0.179 & 0.05 & 0.138 \\
\hline
\end{tabular}

Table 4. The effects of rural municipalities in different fields

\begin{tabular}{cccc}
\hline Factor & Average ratings & Standard deviation & C.V \\
\hline Raising the confidence of the villagers & 2.6 & 0.88 & 0.21 \\
\hline Increasing life management skills & 2.4 & 0.71 & 0.18 \\
\hline Informing the villagers about their potential & 2.3 & 0.69 & 0.15 \\
Providing grounds for job creation & 2.1 & 0.48 & 0.15 \\
\hline Source: Research findings & & JSRD
\end{tabular}

Table 5. Social and cultural effects of rural municipalities

\begin{tabular}{ccc}
\hline Components & Average ratings & Standard deviation \\
\hline Reduce government ownership of rural management & 5.2 & 0.66 \\
Increase public participation & 4.2 & 0.51 \\
The social and cultural context in the villages & 3.1 & 0.41 \\
\hline
\end{tabular}

Source: Research findings 
Statistical analysis shows that Spearman's rank correlation coefficient between the performance of rural municipalities and rural governance is 0.1 and the confidence level of $95 \%$ is reported for the population.

In the studied villages, holding training classes, financial and administrative support, and public participation had a positive effect on the success of rural municipalities.

Statistical analysis of our findings indicates a relationship between participation and rural municipality with a statistical significance of 0.01 , and with a confidence level of $95 \%$, thus it can be argued that there is a significant correlation between social participation and rural municipality success rate in studied villages.

The effect of the rural municipalities on rural infrastructures:

Table 6 illustrates the effect of the performance of rural municipalities variables on qualitative and quantitative variables of rural infrastructures. The average difference shows that there is a significant difference. In other words, rural municipalities have a positive effect on rural infrastructures including roads and infrastructure services, which shows a direct correlation $(\mathrm{SIG}=0.000)$.

The effect of farmers' performance on rural infrastructure:

The effect of the rural municipalities on the market and ancillary activities:
According to the statements of $78.2 \%$ of the villagers, rural municipalities enabled the farmers to participate in ancillary activities. Rural municipalities played a key role in the development of ancillary services, agricultural machinery, agricultural machinery garages, pressurized irrigation, etc. Data analysis shows that $62.3 \%$ of the performance of rural municipalities regarding the market and ancillary activities have a direct relationship with socio-economic issues.

\section{The villagers' evaluation of the performance of ru- ral municipalities:}

Questionnaire results show that the regression coefficient for the performance of rural municipalities is 0.88 with a confidence level of $99 \%$ and a statistical significance of 0.000 . The statistical test in Table 6 suggests that there is a significant correlation between the two variables because the calculated statistical significance is lower than the assumed alpha $(\mathrm{a}=0.07)$. On the other hand, the Chi-squared test results show that $\mathrm{x} 2=307.48$, $\mathrm{df}=4$ and $\mathrm{SIG}=0.000$. Therefore, the correlation between the performance of rural municipalities and villagers' satisfaction is linear.

The data in Table 8 indicate that the performance is significant for cultural, economic and social issues considering the BETA coefficient. Variance analysis of the mean using the Fischer method is also considered positive and significant with (Alpha $<5 \%$ ). Spearman correlation coefficient between the performance of rural municipalities and their success rate is 0.112 . The statistical significance $\mathrm{SIG}=0.000$ with a confidence level of $95 \%$ is another conformation.

Table 6. Significance of the effect of the performance of rural municipalities on quantitative and qualitative variables of infrastructure in the studied areas

\begin{tabular}{ccccc}
\hline Test significance & R & D & Standard deviation & The average difference between A and B \\
\hline 0.000 & 0.9 & 14 & 83.23 & -284 \\
\hline
\end{tabular}

Source: Research findings

Table 7. The coefficient of similarity between the performance of rural municipalities and rural governance

\begin{tabular}{cccc}
\hline \multicolumn{1}{c}{ Variables } & Coexistence coefficient $(\mathbf{r})$ & Sig & Beta \\
\hline Facilities and services in the villages & 0.92 & 0.000 & 0.57 \\
Ensuring the existential philosophy of the villagers & 0.83 & 0.000 & 0.47 \\
\hline Supporting the villagers & 0.75 & 0.000 & 0.41 \\
\hline Source: Research findings & & JSRD
\end{tabular}




\section{Analysis of relationships between variables:}

The statistical results obtained from data related to the performance of rural municipalities as the independent variable and social participation as the dependent variable illustrate that there is a significant relationship between the variables with a confidence level of $99 \%$.

The correlation between the two variables is 0.89 which indicates a direct correlation between the two variables. This means that better performance of rural municipalities on the village level leads to further social participation of villagers in rural management. The results of stepwise regression coefficients of the effect of the performance of rural municipalities on rural governance suggest that rural municipalities have a significant effect on public participation in rural management $(\beta=$ 0.293 ), participation in training classes and promotion of agricultural activities $(\beta=0.288)$ and cooperation with rural councils $(\beta=0.253)$. The results of hypothesis testing indicate a lower value of $\mathrm{p}$ on the alpha level which confirms the positive effect of rural municipalities. Multivariable regression analysis and beta coefficient show a significant direct relationship between variables and $\mathrm{f}$ on the $p=0.01$ level. Linear regression was used to analyze the significance of the relationship between variables and the coefficient of determination was 0.82 . Fisher's statistical value at $99 \%$ confidence level was quite significant and shows that there is a significant relationship between the dependent and independent variables in the equation. The data analysis results of rural municipalities' services and features and rural municipalities' performance show that there is a significant relationship (the level of $\mathrm{p}$ at the alpha level $=0.5$ ) and the calculated correlation coefficient $(\mathrm{r}=0.076)$ indicates a strong and direct relationship between research variables. The cor- relation coefficient between villagers' economic recovery and the performance of rural municipalities is 0.093 and the significance level is 0.051 Our findings reveal that the rural participation variable alone explains $47 \%$ of the variable variance. The rural participation variable explains $66 \%$ of the total research dependent variable variance. It has a great impact on rural governance. Rural municipalities' facilities explain $75 \%$ of research dependent variable variance so that it is directly related to the performance of rural municipalities.

\section{Discussion}

A review of texts related to good rural governance shows that the good rural governance approach is one of the newest and most popular approaches in the field of sustainable rural development management. Relying on the three main pillars of government, the private sector and civil society, this approach emphasizes the active and effective presence of these pillars in the shadow of participation, accountability, rule of law, efficiency and effectiveness, responsibility, consensus and monitoring and human development.

In conclusion, the investigation of rural municipality performance in Zanjan province suggests that today, rural municipalities can play a major role in rural affairs. A rural municipality is a strategy for development and the precise execution of its plan is an obvious necessity and is the foundation of rural development. The rural municipality, as a local organization, has been able to improve components of intergroup social capital and thus, increase public participation in the execution of rural governance plans. The establishment of rural municipalities in Zanjan was one of the basic steps toward rural governance.

Table 8. Multiple regression results of performance evaluation of rural municipalities

\begin{tabular}{cccc}
\hline Variables & Beta & t & sig \\
\hline Cultural & 0.231 & 1.7 & 0.000 \\
\hline Economic & 0.283 & 4.6 & 0.000 \\
\hline Social & 0.249 & 3.7 & 0.000 \\
\hline Performances & 0.258 & 5.9 & 0.000 \\
\hline
\end{tabular}

Source: Research findings

() JSRD

Table 9. The variables and their effect on the dependent variable

\begin{tabular}{|ccccc}
\hline \multicolumn{1}{c}{ Variable } & Correct class\% & Chi-square & df & p \\
\hline 1-The villagers' trust in the municipalities & 89.9 & 109.2 & 2 & 0.000 \\
\hline 2-The level of public awareness of rural performance & 78.2 & 98.3 & 2 & 0.000 \\
\hline Source: Research findings & & & JSRD J
\end{tabular}


$79 \%$ of the sample stated that rural municipalities paved the way for participation and localism. Rural municipalities enabled the villagers to access financial resources, possess legal property rights and motivated them.

In fact, the results showed that rural municipalities in Zanjan provided the opportunity to create a socio-cultural foundation and reduce government involvement in rural affairs.

The results of stepwise regression coefficients $(\beta=$ 0.293 ) indicate the influence of rural municipalities on the rural governance system.

In order to consummate the rural governance system, it is necessary to identify human potential and abilities regarding rural affairs. In order to reach a better level of integration in rural development policy at the regional level, the institutionalization of a participatory model in rural areas, developing a legal framework to empower public organizations, the institutionalization of public participation in the decision-making process, giving authority to public organizations to run rural affairs, and reaching a dynamic level of interaction to strengthen rural governance system and promote participation are necessary. Participatory management methods should be taught to rural municipality administrators to help them reach the maximum participation rate. Strengthening the administrative and organizational structures is one of the basic steps toward rural municipality success. Better financial and administrative support and services and changing the laws regarding granting services and facilities to rural municipalities should also be considered.

\section{Acknowledgements}

This research did not receive any specific grant from funding agencies in the public, commercial, or not-forprofit sectors.

\section{Conflict of Interest}

The authors declared no conflicts of interest.

\section{References}

Ajza Shokouhi, M., Eastgoldi, M. (2013). [Analysis of the underlying factors of good governance, Case study: Turkaman city (Persian)]. Geographical Studies of Arid Regions, 14 (4): 31-49.
Akbari, G. (2003). [Editor's note (Persian)]. Dehyari Monthly, (2)

Akbari, G. (2006). [Social capital and urban governance (Persian)]. Geographical Research Quarterly, 21(4), 135-153

Alavi Tabar, F. (2000). [Participation and Management of Urban Affairs (Persian)]. Tehran: Publications of the Urban Planning Organization.

Alipour, A. (2001). [Study of the performance of Islamic councils of Semnan province (Persian)]. Semnan province governor

Bahrainian, H. (2008). [Report of the first conference of rural industries (Persian)]. Jahad Monthly, 19(222-223).

Barakpour, N., Basirat, M. (2010). [The challenge of rural governance in the metropolitan area of Tehran (Persian)]. Proceedings of the First International Conference on Rural Settlements (pp. 41-52). Tehran: Housing and Texture.

Beer, A. (2014). Leadership and the governance of rural communities. rural studies, 1 (34): 254- 262

Choubchian, S., Kalantari, K., Shaban Ali Fami H.. (2007). [Factors affecting the performance of Rural Municipalities in Guilan province (Persian)]. Village and Development, 10(2), 87-107.

Darban Astane, A., Rezvani, M. R. (2010). [Theoretical explanation of the factors affecting rural governance in Iran (Persian)]. First International Conference on Rural Settlement, Tehran.

Demurger, S., Martin, F., Weiyong, Y. (2010). Rural households decisions towards income diversification: Evidence from a township in northern China. China Economic Review, 21(1), S32-S44.

Elmenofi, G., Bilali, H. E., Berjan, S. (2014). Governance of rural development in Egypt. Annals of Agricultural Science, 59(2), 285-296.

Farahani, H., Rostamkhani, A. (2013). [Study and evaluation of the role of rural development on the quality of life in the villages of Karsaf rural district of Khodabandeh city (Persian)]. Urban Management Quarterly, 30(14), 195-206.

Farokhi, A. (2005). [An Introduction to the Concepts of Development (Persian)]. Tehran: Peyvand Publications.

Ghorbani, F. (2004). [Law of the Fourth Economic, Social and Cultural Development Plan of the Islamic Republic of Iran (Persian)]. Tehran: Ferdows Publications.

Goodwin, M. (1998). The governance of rural areas: Some emerging research issues and agendas. Journal of Rural Studies, 14(1), 5-12. doi: 10.1016/s0743-0167(97)00043-0

Guzal-Dec, D., Zbucki, L., Kus, A. (2020). Good governance in strategic planning of local development in rural and urbanrural gminas of the eastern peripheral voivodeships of Poland. Bulletin of Geography. Socio-economic Series, 50(50) 101-112.

Hamidian, A.R., Javan, J., Yasouri, M. (2007). [Rural Assembly in Rajer's Farming Micro- Culture Theory Case Study: Sabzevar (Persian)]. Geography and Development, 5 (9), 137-160.

Hesam, M., Rezvani, M. R., Ashour, H. (2014). [Measuring the satisfaction of villagers with the performance of rural municipalities with a good rural governance approach, Case study: 
South rural district of Gorgan (Persian)]. geographical planning of space, 14 (4): 99-128.

Heydari Sarban, V., Arshadi, A., Saeb, S. (2017). [Evaluating the effects of governance on the development of rural tourism, case study: Nir city (Persian)]. Tourism Space, 25 (7), 33-50.

Iimani Jajermi, H. (2010). [Sociological study of rural management challenges with a rural governance approach (Persian)] The First International Conference on Rural Settlements. Tehran: Broadcasting Conference Center.

Madani, A. (2003). [Investigating the effect of councils on the decision-making system in villages (Persian)]. Sari: Governorate of Mazandaran province.

Mahdavi, M., Najafikani, A. (2005). [Rural Municipalities: an experience in the management of Iranian villages (Persian)]. Quarterly Journal of Geographical Research, 37(53), 21-39.

Manal R. N., Bachir, A. S., Nadim, K. (2008). Environment and sustainable development indicators in Lebanon: A practical municipal level approach. Ecological Indicators, 8(5), 771-777.

Moghimi, M. (2003). [Management of local government affairs (Persian)]. Tehran: Samt

Morita, S., Zaelke, D. (2007). Rule of Law, Good Governance and Sustainable Development. London: Routledge.

Müller, O., Sutter, O., Wohlgemuth, S. (2020). Learning to LEADER. Ritualised Performances of 'Participation' in Local Arenas of Participatory Rural Governance. Sociologia Ruralis, $60(1), 222-242$.

Najarzadeh, M., Torabi, Z., Malekan, A. (2017). [Investigating the effect of social capital on good governance and sustainability of rural communities with the moderating role of cultural capital, Case study: Godin village of Kangavar city (Persian)]. Spatial planning, 3(7): 25-40.

Nemati, M., Badri, S. A., (2007). [Evaluation of Functional Role of Resent Rural Management System Comparison of Active Rural Municipalities in Small and Big Villages in Golestan Province (Persian)]. Journal of Geographical Research, 39(59), 161-176.

Norouzi, A., Mahdavi, D., Badrizadeh, Z. (2017). [Evaluation of Rural Municipalities' performance in the framework of indicators of good rural governance, Case study: Central part of Isfahan (Persian)]. Rural Research, 8 (4), 652-662.

Norouzifar, H. (2001). [The position of local organizations in the rural management system (Persian)]. (Master dissertation), The University of Tehran, Faculty of Literature and Humanities, Department of Geography.

Parhizkar, A., kazemiyan, G. (2005). [Urban Governance approach and its necessity in the management of the Tehran metropolitan area (Persian)]. Quarterly Journal of Economic Research, 5(16), 29-50.

Pazoki, M., Sheikhi, D., Samadi, Sh. (2020). [Analysis of Management Based on Good Governance Role in Sustainable Rural Development, Case Study: Filestan County, Pakdasht Township (Persian)]. Geography and Development, 18 (58), 93-112.

Rezvani, M. R. (2004). [Introduction to Rural Development Planning in Iran (Persian)]. Tehran: Qoms Publishing
Riahi, V., Karimi Nasab, S. (2013). [Evaluation of Rural Municipalities performance in the spatial physical development of rural settlements (Case study: Kurdish District of Jahrom city) (Persian)]. Journal of Regional Planning, 3(12), 61-70.

Riahi, V., Nouri, A. (2014). [Diversification of Economic Activities and Sustainability of Villages, Case Study: Khorramdareh City. Quarterly Journal of Space Economics and Rural Development, 3(10), 113-128.

[Rural government and sustainable management of the village (Persian)]. (2002). Dehyariha, 1(2), 4-16.

Scott, A. (2001). Global city Region. Oxford University Press.

Taleb, M. (2010). [Integration of rural management using existing legal capacities (Persian)] First International Conference on Rural settlement, Tehran.

United Nations Development Program. (2002). Human development report: Deepening democracy in a fragmented world. New York: United Nations Development Program.

Welch, R. (2002). Legitimacy of rural local government in the new governance environment. Journal of Rural Studies, 18(4), 443-459. doi: 10.1016/s0743-0167(02)00050-5.

Wenchang, W. (2008). Rural management, The Way Out for Tibetan Rural Areas. Journal of the Washington Institute of China Studies, 3(3), 75-84.

Zabetian, J. (2010). [The evolution of theories of Fars province's experience development (Persian)]. The First International Conference on Rural Settlements. Tehran: Broadcasting Conference Center.

Zankin, F. (2010). local government, new approach, pum university 
